\title{
The Effect of Religiosity and Self-Efficacy to Improve Students' Literacy: A Study on Academic Cheating
}

\author{
Siti K. Khotimah ${ }^{1, *}$ Ainun Nadhirah ${ }^{2,}$ Fathin Fadhilah ${ }^{3,}$ Netty Herawati ${ }^{4}$ \\ ${ }^{1,2}$ UIN Sunan Ampel Surabaya, Surabaya, Indonesia \\ ${ }^{3}$ Universitas Negeri Surabaya, Surabaya, Indonesia \\ ${ }^{4}$ Universitas Trunojoyo, Bangkalan, Indonesia \\ "Corresponding author.Email: khotim_psi@yahoo.com
}

\begin{abstract}
This study aims to determine the effect of religiosity and self-efficacy to improve students' literacy on students' academic cheating partially and simultaneously. It was explanatory survey research that highlights the relationship between research variables by testing the hypotheses that had been formulated previously. This research was conducted at MI An-Nur (pseudonym) (Islamic elementary school) in East Java, with a sample of 81 students from 516 of the total population. The data were collected by using the questionnaire method as a self-report, in which students are asked to answer the questions by choosing an answer that suits them, Religiosity Scale, Self-efficacy Scale, and Academic Cheating Scale. All scales had already tested the validity with product-moment and the reliability was tested with Cronbach Alpha. The results were that all items used in this study were valid and reliable. Data analysis was done to determine the effect of each variable partially and simultaneously. The data analysis techniques in this study used multiple linear regression analysis models with F-test and T-test. The Findings were: (1) religiosity affected students' academic cheating, (2) self-efficacy did not affect students' academic cheating, and (3) religiosity and self-efficacy affected students' academic cheating simultaneously.
\end{abstract}

Keywords: Academic cheating, Religiosity, Self-efficacy, Literacy.

\section{INTRODUCTION}

The education system in Indonesia pays more attention to the development of students' honesty as part of the goals of national education as stated in The National Education System Law No. 20 of 2003 that the function of National Education is to develop capabilities and shape the character and civilization of a dignified nation to educate the nation's life. The purposes are to develop the potential of students to become human beings who believe in and are obedient to God Almighty, have a noble character, healthy, knowledgeable, capable, creative, independent, become democratic and responsible citizens. To support its implementation, the Ministry of National Education has issued School Guidelines, Development of Cultural Education, and National Character which puts honesty as one of the 18 values that must be developed at schools. It applies to all levels of formal education, both public schools and religion-based schools such as madrasa [1].

One of the problems in education is academic dishonesty such as academic cheating. It becomes a concern because of the impact of this academic dishonesty. In the short term, teachers cannot measure student learning outcomes appropriately, students will get grades according to their cheating results, which are different from their real academic abilities [2], [3]. In the long term, academic cheating will develop dishonest behavior in later education. Several studies show that the number of students of elementary, middle, and high school to undergraduate students who commit academic dishonesty tends to increase [4]-[6]. Another impact is that students who cheated tend to cheat in the workplace [3], [7], [8]. They will tend to look for shortcuts in solving their problems by cheating at work or other activities [9], [10].

Students' academic cheating behavior is very diverse. McCabe \& Trevino [8] examined 12 academic dishonesty behaviors in the form of; (1) using cheats in exams, (2) imitating other students during exams, (3) using fraudulent methods to find out questions that might be missed, (4) imitating friends' answers during exams without their knowledge, (5) helping other people during exams, (6) cheating in the exam in other ways, (7) 
copying certain material and making it look like our work, (8) falsifying biographies, (9) ordering other people to do their work, (10) getting help for independent assignments (without permission), (11) working together on independent assignments, and (12) copying sentences or materials from certain sources without recording them as references.

It is understood that academic dishonesty consists of 4 categories, namely cheating, providing false information, facilitating academic dishonesty, and plagiarism, but the common studies of academic dishonesty at elementary school to high school are cheating behavior [2], [5], [11]-[17]. Groak states that technological developments such as phones, computers, and the internet have supported the increasing prevalence of cheating behavior [18].

In 2019, the Indonesian Inspectorate General of the Ministry of Education and Culture noted that there were 202 complaints of academic cheating during the implementation of the SMA/SMK/MA National Examinations (UN). However, after being verified, it became 126 cases. These complaints tend to increase from year to year. It is noted that in 2017,71 participants were indicated to have cheated, in 2018 only 79 participants, and in 2019, the most verified cases were 126. One of the identified forms of cheating in the UN is taking photos of questions from a computer and sharing them which is done from a cellphone [1]. Previous research in Madrasa found that cheating behavior at the 2015 National Examination for MA/ Islamic Senior High Schools in East Java was very high [19].

It is unfortunate because, at Madrasah or Islamic Schools, students should learn more about how to behave properly by Islamic role. Jalaluddin states that madrasa as educational institutions have been recognized as part of the formal education system in which one of the Islamic education goal dimensions is the moral dimension, as the human nature to do good and right [20]. It is in line with the Ministry of Religion vision, that madrasa should develop students to become a generation with integrity, character, and noble character [19]. As part of a Muslim school, madrasa teachers are obliged to educate students to behave honestly, as conveyed by the Prophet Muhammad:

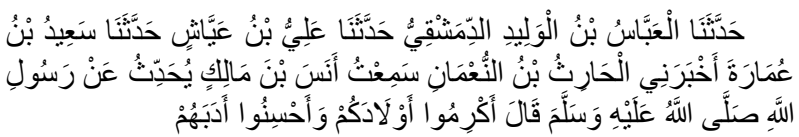

It means: Has told us (1 'Abbas bin Al Walid Ad Dimasyqi) has told us (Ali bin 'Ayyash) has told us (Sa'id bin 'Umarah) has told me (Al Harith bin AnNu'man) I heard (Anas bin Malik) from the Prophet sallallaahu 'alaihi wasallam, He said: "honor your children and correct their behavior."

Academic cheating is despicable behavior. Cheating is a "rule violation" where students show abilities or knowledge that are not real [12]. Cheating behavior is an act of cheating committed by someone to achieve academic success by plagiarizing, imitating, and or imitating the work of others, either with or without the permission of the owner [21]. Cheating behavior is all behavior seeking, giving and obtaining answers or incorrectly completing academic assignments, imitating or deceiving others [3].

Cheating is related to the behavior of not only doing exams at school but also doing homework that must be done independently but it is done with the help of others without the teacher knowing or the teacher mistaking it as students work independently. Cheating includes the behavior of imitating books/notes to do assignments and exams, copying small notes during exams, and imitating friends' answers when doing assignments and exams [5], [22], [23].

Various previous studies examine cheating behavior in terms of various factors. Several studies on the variables that influence students' cheating behavior are goal orientation [17], positive thinking [14], academic self-concept [21], religiosity [24], [25], self-efficacy [26]-[28], and the lack of the function of education as a transfer of value but only as a transfer of knowledge [29].

In general, the tendency of students to behave honestly or dishonestly is influenced by personal factors and situational factors [9], [30], [31], and teacher factors [32]. Situational factors include conditions outside the individual that can affect his tendency to do academic cheating, including; the size of the institution, size of classrooms, seating in class, difficulty with assignments or exams or classes, teaching methods, fear of being arrested, punishment, which students will weigh the benefits and penalties involved in deciding to cheat, and so on. Personal factors, related to individual characteristics, including; gender, work ethic, personality, organizational membership, stress, intelligence, moral judgment and will, and others.

This study will focus on personal factors, especially the influence of religiosity and self-efficacy on academic cheating in madrasa students. Moral problems such as cheating can start at the age of 10 and 11 years, where at this age students begin to develop ways of thinking in facing dilemmas to complete academic tasks honestly or not [33].

The ability to manage internal and external impulses in a dilemmatic situation manifested in behavior is related to the child's moral reasoning ability [34]. According to Kohlberg, each individual goes through 6 stages of moral reasoning, starting from the first stage which considers behavior as other people's views, as well as external control, to the $6^{\text {th }}$ stage which is internally regulated, individual moral considerations are based on internal control / internal values that are believed. Related to academic cheating, external control will be effective if 
the individual is still at a low level, and conversely, the higher the level of individual moral reasoning, the higher the internal regulation. This moral reasoning is related to the religiosity of students.

Students' level of religiosity will affect their daily behavior. A person's diversity is manifested not only when worshiping rituals, but also in good behavior in managing external and internal impulses [35]. According to Nashori, religiosity is how far the knowledge is, how strong the belief is, how much worship and rules are implemented, and how deep is the appreciation of the religion adopted [36]. El-Menouar reveals that there are 5 dimensions of religiosity in Muslims which were developed from the concept of religiosity of Glock \& Clark [37]. The five dimensions of Muslim religiosity from El-Menouar are (1) religious basic which includes belief and loyalty, (2) religious main obligations which include the application of the 5 pillars of Islam, (3) religious experience, (4) religious knowledge, and (5) orthopraxis, the consequences of religious practice in daily behavior. As Muslims, cheating is prohibited behavior, so students with high religiosity will tend to avoid it.

In Madrasa, Islamic norms practices are more than regular school, and this religious institution affects students' religiosity [32]. Religious education given to students should prevent negative behavior, including cheating [25]. In Madrasah Ibtidaiyah, where the environment tends to be religious, are expected to support the development of student religiosity, because as stated by Clark et al that in childhood ( $0-12$ years) they tend to record the behavior around them [38]. Students' religiosity level is strongly influenced by the environment. It is strongly influenced by the religious education obtained at the madrasa that can foster attitudes and abilities in distinguishing between good and bad behavior, including cheating.

Another variable that predicts can affect academic cheating is self-efficacy. The importance of self-efficacy as a predictor of motivation and student learning activities [39]. Self-efficacy beliefs were found to be sensitive in the context of changes in student performance, in interacting with self-regulated learning processes, and mediating student academic achievement.

Self-efficacy refers to the belief in the extent to which an individual estimate his ability to carry out a task or perform a task required to achieve a certain result [40]. These abilities include self-confidence, adaptability, cognitive capacity, intelligence, and capacity to act in stressful situations. Self-efficacy will develop gradually and continuously as abilities and related experiences increase.

Bandura says that self-efficacy has a major influence on behavior [41]. For example, the student with low selfefficacy may not want to try to study for an exam because he does not believe that studying will help him to do the problem. Bandura suggests several dimensions of selfefficacy, namely: magnitude, generality, and strength. Magnitude is related to the level of difficulty of a task being carried out. Generality is related to the field of work, how broadly individuals have confidence in carrying out tasks. Strength is related to the strength and weakness of an individual's belief.

In this study, self-efficacy is defined as an individual's belief about his ability to organize and complete a task needed to achieve certain results. Confidence in one's abilities makes one able to optimize his efforts to achieve an academic goal. When a student feels confident that he can complete academic demands, he will not commit fraud. This is supported by the results of research that good self-efficacy can reduce students' tendency to cheat [28].

Simultaneously, another research also shows that there is a negative correlation between students' selfconfidence and religiosity towards cheating behavior [42]. In this study, it was found that positive individual values about themselves and their abilities can foster selfconfidence and have a good impact on students' learning processes.

However, several studies show different results. Reference [43] reveals their finding are different from research in general, where religiosity is not directly or indirectly related to the cheating behavior of Islamic high school students in Semarang. Regarding the effect of selfefficacy on academic cheating, self-efficacy does not affect academic cheating in accounting students [35]. On the simultaneous effect, from that study, it was known that the opportunity, self-efficacy, and religiosity factors did not affect academic cheating.

From this explanation, it can be seen that among the personal factors that influence students' cheating behavior are religiosity and self-efficacy, wherefrom several research results it is known that there are research results that show their effect on students' cheating behavior and some show that it has no effect. In addition, no research examines these two variables simultaneously on cheating behavior in elementary school or MI students.

This is a concern for researchers to test the effect of these variables on students' academic cheating at Madrasah Ibtidaiyah. This study aims to determine the effect of religiosity and self-efficacy on students' academic cheating at Madrasah Ibtidaiyah (Islamic elementary school) either partially and simultaneously.

\section{METHODS}

Based on the research objectives, the researcher used an explanatory survey research type that highlights the relationship between research variables by testing the 
hypotheses that have been formulated. The hypothesis according to previous literature review as Figure 1.

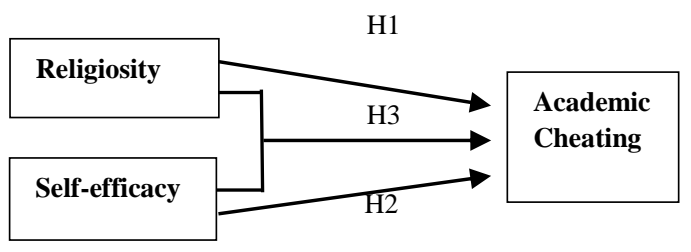

Figure 1. Theoretical Framework.

Figure 1 illustrates the hypothesis that there is a partial and simultaneous influence of religiosity and selfefficacy on MI students' academic cheating. This study aims to determine the effect of religiosity and selfefficacy on students' academic cheating partially and simultaneously. This research was conducted at MI AnNur (pseudonym) at East Java, with a sample of 81 students from 516 students as the population. This sample was determined by purposive sampling, where the researcher determined the sample criteria for some of the $4^{\text {th }}$ and $5^{\text {th }}$ - grade students of MI An-Nur, both boy and girl. These criteria related to the study that at the age of 10 and 11 years, students' moral problems such as cheating can start, where they begin to develop their ways of thinking in facing dilemmas, to be honest or not to complete their tasks [33]. It is also related to the child's moral reasoning ability [34].

The data was collected by using a questionnaire which was prepared as a self-report. Students were asked to choose the answer that suits them. For this reason, 4 answer scales are provided; very suitable (SS), suitable (S), not suitable (TS), and very unsuitable (STS) in emoticon form that is more familiar to students. The validity was tested with product-moment and then tested its reliability with Cronbach Alpha. It is known that all items are valid and reliable.

The dependent variable is academic cheating, a students' tendency to cheat known from the attitude of agreeing or disagreeing and plans to: (1) copy books/notes to do assignments and exams, (2) imitate small notes during exams, and (3) imitate friends' answers when doing assignments and exams. Questionnaires were given in 2 aspects, students' attitudes and tendencies toward academic cheating. The questionnaire consisting of 20 items is known to be valid and reliable with an alpha coefficient of 0.857 .

The independent variables in this study were religiosity and self-efficacy. Religiosity is defined as the extent of knowledge, how solid beliefs are, how much worship and rules are implemented, and how deep is the appreciation of the religion adopted, which is measured through the 5 religious dimensions of Muslims from ElMenouar [37]: (1) religious basic, (2) religious main obligations, 3) religious experience, (4) religious knowledge, and (5) orthopraxis, the consequences of practice in daily behavior. The religiosity scale consists of 29 items that have passed the validity and reliability test with a reliability coefficient of 0.793 .

Self-efficacy is an individual's belief about his ability to organize and complete a task needed to achieve a certain result. Self-efficacy is measured based on Bandura's self-efficacy dimension [40]: (1) magnitude, (2) generality, and (3) strength. After confirming with validity and reliability tests on 25 items on the SelfEfficacy Scale, it is known that $r=0.857$ indicates that this item is reliable.

\section{RESULTS AND DISCUSSIONS}

\subsection{Result}

After testing the assumptions and it is known that the data meets the normality test, then a hypothesis test is carried out. The t-test was used to test the effect of X1 (Religiosity) on Y (Academic Cheating) and the effect of X2 (Self-efficacy) on Y partially, and the F-test was used to test the effect of $\mathrm{X} 1$ and $\mathrm{X} 2$ on $\mathrm{Y}$ simultaneously.

Table 1. Coefficient

\begin{tabular}{|c|c|c|c|c|c|c|}
\hline \multicolumn{2}{|c|}{ Model } & \multicolumn{2}{|c|}{$\begin{array}{c}\text { Unstandardized } \\
\text { Coefficients }\end{array}$} & $\begin{array}{c}\text { Standardized } \\
\text { Coefficients }\end{array}$ & t & Sig. \\
\cline { 2 - 7 } & B & $\begin{array}{c}\text { Std. } \\
\text { Error }\end{array}$ & Beta & & \\
\hline \multirow{2}{*}{1} & (Constant) & 3.348 & 0.554 & & 6.046 & 0.000 \\
\cline { 2 - 8 } & X1 & -0.483 & 0.174 & -0.324 & -2.779 & 0.007 \\
\cline { 2 - 7 } & X2 & -0.057 & 0.115 & -0.058 & -0.496 & 0.621 \\
\hline
\end{tabular}

aependent Variable: Y

From Table I, it's known:

1. Hypothesis test $\mathrm{I}$ showed the value of $\mathrm{t}=-2.2779$ with sig 0.007 . This shows that the level of religiosity affects the student's academic cheating

2. From the results of hypothesis testing II, the value of $t=-0.496$, sig 0.621 . This shows that self-efficacy has no effect on students' academic cheating, or the second hypothesis is rejected.

Table 2. Anova

\begin{tabular}{|c|c|c|c|c|c|}
\hline Model & $\begin{array}{c}\text { Sum of } \\
\text { Squares }\end{array}$ & df & $\begin{array}{l}\text { Mean } \\
\text { Square }\end{array}$ & $F$ & Sig. \\
\hline Regression & 1.484 & 2 & 0.742 & 5.522 & $0.006^{\mathrm{b}}$ \\
\hline Residual & 10.484 & 78 & 0.134 & & \\
\hline Total & 11.969 & 80 & & & \\
\hline
\end{tabular}

aDependent Variable: Y

bPredictors: (Constant), X2, X1

From Table II, it is known that the results of the third hypothesis test, $\mathrm{F}=5.522$ with a significance of 0.006 . This shows that the level of religiosity and self-efficacy 
simultaneously affect the students' academic cheating. To determine the proportion or percentage of the total variation in the $\mathrm{X}$ variable explained by the $\mathrm{Y}$ variable, it is known from the coefficient of determination as follows:

Table 3. Model Summary

\begin{tabular}{|r|c|r|c|c|}
\hline Model & $R$ & R Square & $\begin{array}{c}\text { Adjusted R } \\
\text { Square }\end{array}$ & $\begin{array}{c}\text { Std. Error of } \\
\text { the Estimate }\end{array}$ \\
\hline 1 & $0.352^{\mathrm{a}}$ & -124 & 0.102 & 0.367 \\
\hline
\end{tabular}

From Table III, the value of the coefficient of determination seen from the Adjusted R Square value is 0.102 , meaning that the magnitude of the influence of the $\mathrm{Y}$ variable on the $\mathrm{X}$ variable is $10.2 \%$, while the rest $(89.8 \%)$ is explained by other variables outside this study.

\subsection{Discussion}

Based on the results of hypothesis testing about the effect of religiosity on academic cheating, it is known that the value of $\mathrm{t}=-2.2779$ with sig 0.007 , which means that the level of religiosity negatively affected students' academic cheating. The higher the level of student religiosity, the lower their academic cheating will be. On the other hand, students with low levels of religiosity tended to cheat easily.

It is in line with the previous research that religiosity has a negative effect or tends to reduce academic dishonesty [44]. Similarly, another research found that the higher the level of student religiosity, the lower the level of academic cheating [24]. This is also in line with another research which revealed that religious knowledge was the main predictor of honest behavior in academic settings [45]. Other research also found that students with a high level of religiosity, which was well illustrated by beliefs and appreciation in religion as well as religious knowledge and practices, contributed to suppressing cheating behavior until they were in the moderate category [46].

This is possible, when students have sufficient religious knowledge, they will be able to properly consider alternative attitudes to be taken when they have difficulties in completing academic tasks. At the age of 10-11, students begin to develop a way of thinking in dealing with dilemma choices to complete academic tasks honestly or not [33]. With religious knowledge, it can be an ingredient in students' moral considerations which continue to develop from external control to internal control [34]. The higher individual's internal control, the more to avoid wrong behavior such as academic cheating.

From the research results on the effect of self-efficacy on academic cheating, the value of $t=-0.496$, sig 0.621 , which means that when self-efficacy increases by one unit, then academic cheating will decrease in -0.496 units, with the assumption that other independent variables value is fixed. The significance 0.621 , more than 0.005 , indicates that self-efficacy did not affect the tendency of students to cheat.

It is different from several previous studies that showed the relationship or influence of self-efficacy on the tendency of students to cheat [28], [44], [47]. As Murdock said that from several predictors of cheating behavior, self-confidence was one of the strongest. Students who had a low perception of their abilities, tend to cheat [11]. As Bandura said that students' behavior was influenced by their self-efficacy [41] students with high self-efficacy would organize themselves, such as studying for a test because they believed their ability and study would make them ready for the test. The result that self-efficacy did not affect academic cheating, in line with other research that self-efficacy had no significant effect on academic fraud [35]. Students' tendency to cheat was not affected by their self-efficacy.

In this study, self-efficacy which did not affect academic cheating, is possible for several things. First, academic cheating is influenced by situational and personal factors [9]. Self-efficacy is part of personal factors, where many personal factors have not been studied and also situational factors that may have a greater influence on MI students' academic cheating. Other research shows that peer pressure, environmental, and the assumption that academic dishonesty is normal, affect their tendency to cheat [48].

Second, other variables can mediate the relationship between self-efficacy and academic cheating. Other research showed that self-efficacy gave a negative effect on academic cheating depending on the disposition of patience [49]. The higher student's disposition of patience, the higher the negative effect of self-efficacy on academic cheating is. The next researcher may consider examining other variables that mediated the effect of selfefficacy on academic cheating.

The results of the simultaneous test of the influence of religiosity and self-efficacy on academic cheating obtained a value of $\mathrm{F}=5.522$ with a significance of 0.006 , indicating that the level of religiosity and selfefficacy simultaneously influenced the tendency of students to cheat. This research is in line with Ula \& Sholih Research on MTs Mazra'atul Ulum PaciranLamongan that there was a negative correlation between self-efficacy with students' cheating behavior. The higher students' self-efficacy and religiosity, the lower their intensity to cheat, and vice versa.[50].

This result is also in line with other research about self-confidence and religiosity to cheating behavior [42]. It was concluded that students with high self-confidence and religiosity will tend to avoid cheating and vice versa. The good attitude of religiosity that students have, can 
develop the boundaries between good and bad and always feel supervised by God, support their selfconfidence and they will tend to use their ability in completing an academic task and avoid academic cheating.

From the partial analysis in this study, it is known that religiosity affects students' moral reasoning so that students with a high level of religiosity will tend to avoid cheating. In the analysis of social learning theory, behavioral choices are determined by perceptions of selfefficacy rather than driven by the environment [40]. When self-efficacy along with religiosity (knowledge, experience, and other dimensions of religiosity) will lead students to consider attitude choices when faced with the possibility to cheat or not. The higher level of students' religiosity and the higher their self-efficacy, the more they avoid academic cheating and develop learning activities that support their achievement.

From the coefficient of determination Adjusted $\mathrm{R}$ Square $=0.102$, it is known that the magnitude of the influence of the $\mathrm{Y}$ variable on the $\mathrm{X}$ variable is $10.2 \%$, while the rest, $89.8 \%$, is explained by other variables outside this study. As is known, the factors that influence academic cheating are personal and situational [9]. So it can be understood, if there are still many other variables that affect student academic cheating besides religiosity and self-efficacy, both from personal and situational factors.

Second, research subjects who are in childhood are known to be strongly influenced by situational factors. There are some situational factors known to influence students' academic cheating. Eisenberg said that class norms affect students' behavior to cheat or not [51]. When the classes tend to classify students who do not want to cheat as stupid students, and who do not cheat as selfish students, then the students will tend to do academic cheating.

Other research found that students' perception of teachers' reference norm orientation (IRNO) is associated with students' cheating [52]. The higher students' reported cheating on their written exams or their homework, the less their collectively perceived their teacher's IRNO.

According to Clark et al, in childhood ( $0-12$ years) they tend to record the behavior around them [38]. Students' tendency to cheat is affected by environmental and peer pressure [48]. When the environment and peers assume that academic dishonesty is normal, they will tend to cheat, and they will tend to avoid cheating when the environment and peers assume that academic dishonesty is wrong.

Academic cheating is strongly influenced by external/environmental controls, one of which is fear of punishment. This is especially true if children are still in the pre-conventional morality stage [34]. If the environment supports their cheating behavior, with value rewards or peer support, for example, it will further strengthen it, but if they get information about punishment or negative consequences of cheating, they will avoid it even more.

\section{CONCLUSION}

From this study, the conclusions are: (1) religiosity significantly affects students' literacy in the academic cheating, (2) self-efficacy does not significantly affects students' literacy in the academic cheating, and (3) religiosity and self-efficacy significantly affect students' literacy in the academic cheating simultaneously. From these studies, we propose some recommendations. Practically, there are some recommendations. To support students' academic honesty that leads the students to avoid cheating, teachers need to develop students' religiosity that affects their moral reasoning in facing a dilemma, through discussions and any other religious activities. This discussion needs to be linked to support their self-efficacy. The higher students' religiosity and the higher their self-efficacy development through religious activities and religious discussion, it can support their academic honesty. About the possibility of situational factors that affected the student's academic cheating, a school needs to develop these situational factors. Schools should clarity the consequences of academic cheating because the students are different on their moral reasoning level. Even though at elementary school age, some students have started to develop moral reasoning towards internalization, some others are in the lower level, that more affected by fear of punishment. The clarification of the consequences of cheating is also supported by the school norms. In theoretical recommendation, research on students' academic cheating still needs to be developed. Next researchers can develop studies about other factors that can affect academic cheating, including factors with intervening variables. Action research and experiment research can be developed to test some interventions to support students' academic honesty to prevent academic cheating.

\section{AUTHORS' CONTRIBUTIONS}

All authors conceived and designed this study. All authors contributed to the process of revising the manuscript, and at the end all author have approved the final version of this manuscript.

\section{REFERENCES}

[1] A. P. Abdi, "Kemendikbud catat 126 kecurangan selama Ujian Nasional 2019," 2019. https://tirto.id/kemendikbud-catat-126-kecuranganselama-ujian-nasional-2019-drNd. 
[2] B. B. Houser, "Student cheating and attitude: A function of classroom control technique," Contemp. Educ. Psychol., vol. 7, no. 2, pp. 113-123, 1982.

[3] S. F. Davis, P. F. Drinan, and T. B. Gallant, Cheating in school: What we know and what we can do. John Wiley \& Sons, 2011.

[4] J. N. Smith and R. F. Nolan, "Faculty perception of student academic honesty.," Coll. Stud. J., vol. 32, no. 2, pp. 305-310, 1998.

[5] E. M. Anderman and C. Midgley, "Changes in selfreported academic cheating across the transition from middle school to high school," Contemp. Educ. Psychol., vol. 29, no. 4, pp. 499-517, 2004.

[6] T. C. Grijalva, J. Kerkvliet, and C. Nowell, "Academic honesty and online courses," Coll. Stud. J., vol. 40, no. 1, 2006.

[7] S. Nonis and C. O. Swift, "An examination of the relationship between academic dishonesty and workplace dishonesty: A multicampus investigation," J. Educ. Bus., vol. 77, no. 2, pp. 6977,2001

[8] B. E. Whitley Jr and P. Keith-Spiegel, Academic dishonesty: An educator's guide. Psychology Press, 2001.

[9] H. E. Kaufman, "Moral and ethical issues related to academic dishonesty on college campuses," J. Coll. Character, vol. 9, no. 5, pp. 1-8, 2008.

[10] O. Rujoiu and V. Rujoiu, "Academic dishonesty and workplace dishonesty: an overview," in Proc. Int. Manage. Conf, 2014, vol. 8, pp. 928-938.

[11] T. B. Murdock, N. M. Hale, and M. J. Weber, "Predictors of cheating among early adolescents: academic and social motivations," Contemp. Educ. Psychol., vol. 26, no. 1, pp. 96-115, 2001.

[12] Y. Tas and C. Tekkaya, "Personal and contextual factors associated with students' cheating in science," J. Exp. Educ., vol. 78, no. 4, pp. 440-463, 2010.

[13] N. K. Hartosujono \& Sari, "Perilaku menyontek pada remaja," J. Psikol., vol. 20, no. 2, 2015.

[14] K. Nurmayasari and H. Murusdi, "Hubungan antara berpikir positif dan perilaku menyontek pada siswa kelas X SMK Koperasi Yogyakarta.” Universitas Ahmad Dahlan, 2015.

[15] S. K. Khotimah, "Rising student's academic honesty: the implementation of classroom developmental bibliotherapy (CDB) in Bahasa Indonesia learning at Madrasah Ibtidaiyah," JPDI (Jurnal Pendidik. Dasar Indones., vol. 2, no. 2, pp. 28-34, 2017.

[16] S. K. Khotimah, M. I. Fadhli, and Y. Habibi, "Meningkatkan kejujuran akademik: Efektivitas classroom developmental bibliotherapy dalam pembelajaran," Humanit. J. Psikol. Indones., vol. 14, no. 2, 2017.

[17] A. N. Septiani, A. Nayazik, and P. Kurniawan, "Hubungan goal orientation dengan perilaku menyontek siswa Sekolah Menengah Pertama," J. Medives J. Math. Educ. IKIP Veteran Semarang, vol. 3, no. 2, p. 307, 2019, doi: 10.31331/medivesveteran.v3i2.840.

[18] Mujahidah, "Perilaku menyontek laki-laki dan perempuan: Studi meta analisis," J. Psikol., vol. II, no. 2, pp. 177-199, 2009, [Online]. Available: http://digilib.uin-suka.ac.id/id/eprint/8860.

[19] Kusaeri, "Studi perilaku cheating Siswa Madrasah dan Sekolah Islam ketika Ujian Nasional," Edukasia J. Penelit. Pendidik. Islam, vol. 11, no. 2, pp. 331-354, 2016, doi: 10.21043/edukasia.v11i2.1727.

[20] I. Syafe'i, "Tujuan pendidikan Islam," $A l$ Tadzkiyyah J. Pendidik. Islam, vol. 6, pp. 151-166, 2015.

[21] Samiroh and Z. I. Muslimin, "Hubungan antara konsep diri akademik dan perilaku menyontek pada siswa- siswi Mas Simbangkulon Buaran Pekalongan,” Psikis, vol. 1, no. 2, pp. 67-77, 2016.

[22] E. J. Vinski and G. S. Tryon, "Study of a cognitive dissonance intervention to address high school students' cheating attitudes and behaviors," Ethics Behav., vol. 19, no. 3, pp. 218-226, 2009.

[23] K. P. Nasional, Pengembangan pendidikan budaya dan karakter bangsa. Jaka: Kementerian Pendidikan Nasional, 2010.

[24] E. Shafina, M. Mardi, and A. Fauzi, "The effect of pressure, rationalization, religiosity on academic fraud behavior," Int. J. Econ. Bus. Account. Res., vol. 5, no. 2, 2021.

[25] I. Mastiyah, "Religiusitas siswa Madrasah Aliyah dan Sekolah Menengah Atas," EDUKASI J. Penelit. Pendidik. Agama dan Keagamaan, vol. 16, no. 3 , pp. 232-246, 2018, doi: 10.32729/edukasi.v16i3.484. 
[26] E. Pudjiastuti, "Hubungan self efficacy dengan perilaku mencontek mahasiswa psikologi," Mimb. J. Sos. Dan Pembang., vol. 28, no. 1, pp. 103-111, 2012.

[27] S. H. Amelia, Z. Tanjung, E. Riyant, R. Azizi A.M, M. N. N. Novita, and Ranny, "Perilaku menyontek dan upaya penanggulangannya," JRTI (Jurnal Ris. Tindakan Indones., vol. 1, no. 1, pp. 1-6, 2016, [Online]. Available: http://jurnal.iicet.org/index.php/jrti\%0Attp://jurnal. iicet.org/index.php/jrti PERILAKU.

[28] Antasari, O. Pandansari, R. Susanti, Kurniawati, and A. Aziz, "Pengaruh efikasi diri terhadap perilaku menyontek siswa Sekolah Dasar selama pembelajaran daring," J. ilmu Penelit. Ilmu Pendidik., vol. 14, no. 1, pp. 82-90, 2021.

[29] I. Angelia, "Menyontek sebagai bagian dari dekadensi moral bangsa," J. Civ. Educ., vol. 2, no. 2, pp. 120-125, 2019, doi: 10.24036/jce.v2i2.125.

[30] L. Zhao et al., "Using environmental nudges to reduce academic cheating in young children," Dev. Sci., vol. 24, no. 5, pp. 1-8, 2021, doi: $10.1111 /$ desc. 13108 .

[31] W. Dejene, "Academic cheating in Ethiopian secondary schools: Prevalence, perceived severity, and justifications," Cogent Educ., vol. 8, no. 1, 2021, doi: 10.1080/2331186X.2020.1866803.

[32] A. Asrifan, A. Ghofur, and N. Azizah, "Cheating behavior in EFL classroom (a case study at Elementary School in Sidenreng Rappang Regency)," OKARA, vol. 14, no. 02, pp. 279-297, 2020, doi: 10.19105/ojbs.v14i2.4009.

[33] C. Semerci, "The opinions of medicine faculty students regarding cheating in relation to Kohlberg's moral development concept," Soc. Behav. Personal. an Int. J., vol. 34, no. 1, pp. 4150, 2006.

[34] L. Kohlberg, Moral stages and moralization: the cognitive-development approach, moral development and behavior, theory, research and social issues. New York: Holt, Rinehart and Winston, 1976.

[35] I. N. Melati, R. Wilopo, and I. Hapsari, "Analysis of the effect of fraud triangle dimensions, selfefficacy, and religiosity on academic fraud in accounting students," Indones. Account. Rev., vol. 8, no. 2, pp. 187-202, 2018.

[36] I. F. Reza, "Hubungan antara religiusitas dengan moralitas pada remaja di Madrasah Aliyah (MA)," Humanit. J. Psikol. Indones., vol. 10, no. 2, pp. 45$58,2013$.

[37] A. Zhafira, "Efek moderasi kepercayaan politik terhadap hubungan antara religiusitas Islam dan intoleransi politik," J. Psikol. Sos., vol. 15, no. 2, pp. 122-135, 2017.

[38] E. Kartikowati and Zubaedi, Psikologi agama \& psikologi islami sebuah komparasi, 1st ed. Jakarta: Kencana, 2016.

[39] B. J. Zimmerman, "Self-efficacy: An essential motive to learn," Contemp. Educ. Psychol., vol. 25, no. 1, pp. 82-91, 2000.

[40] A. Bandura, "Self-efficacy: toward a unifying theory of behavioral change," Psychological Review, vol. 84, no. 2. pp. 191-215, 1977.

[41] J. W. Santrock, Psikologi pendidikan edisi kedua, terjemahan Tri Wibowo BS, vol. 357. 2008.

[42] E. Kusdiana, M. A. Djalali, and M. Farid, "Percaya diri, religiusitas dan perilaku menyontek," JKI (Jurnal Konseling Indones., vol. 3, no. 2, pp. 37-41, 2018, doi: 10.21067/jki.v3i2.2214.

[43] I. Hadjar, "The effect of religiosity and perception on academic cheating among muslim students in Indonesia," J. Educ. Hum. Dev., vol. 6, no. 2, pp. 139-147, 2017.

[44] S. Khumaeroh, E. Purwanto, and A. Awalya, "Selfefficacy, goal orientations, and religious moral orientations on academic dishonesty," J. Bimbing. Konseling, vol. 8, no. 3, pp. 20-25, 2019.

[45] R. Ridwan and Y. Diantimala, "The positive role of religiosity in dealing with academic dishonesty," Cogent Bus. Manag., vol. 8, no. 1, p. 1875541, 2021.

[46] A. Karim, A. Munir, and Hasanuddin, "Hubungan religiusitas dan sikap guru dengan perilaku menyontek pada siswa SMA Swasta Islam Al-Ulum Terpadu Medan," Tabularasa J. Ilm. Magister Psikol., vol. 3, no. 2, pp. 145-153, 2021, doi 10.31289/tabularasa.v3i2.659.

[47] G. M. Priaswandy, "Hubungan antara self efficacy dengan perilaku menyontek pada siswa kelas xi di sma negeri 1 Pleret Bantul Yogyakarta," J. Ris. Mhs. Bimbing. Dan Konseling, vol. 4, no. 6, 2015.

[48] S. Miranda and C. Freire, "Academic dishonesty: Understanding how undergraduate students think 
and act," Proc. 15th ISATT 2011-Back to Futur. legacies, Contin. Chang. Educ. policy, Pract. Res. Univ. do Minho, Braga., 2011.

[49] F. Rozi, "The role of patience disposition on the effect of self-efficacy on academic cheating," Psikis J. Psikol. Islam., vol. 7, no. 1, pp. 20-30, 2021.

[50] A. H. Ula and A. K. Sholeh, "Perilaku menyontek siswa di MTs," Psikoislamika J. Psikol. dan Psikol. Islam, vol. 11, no. 1, pp. 33-38, 2014.

[51] J. Eisenberg, "To cheat or not to cheat: effects of moral perspective and situational variables on students' attitudes," J. Moral Educ., vol. 33, no. 2, pp. 163-178, 2004.

[52] T. Marksteiner, A. K. Nishen, and O. Dickhäuser, "Students' perception of teachers' reference norm orientation and cheating in the classroom," Front. Psychol., vol. 12, no. February, 2021, doi: 10.3389/fpsyg.2021.614199. 